\title{
M\&A Contracts: Purposes, Types, Regulation, and Patterns of Practice
}

\section{Citation}

John C. Coates IV, M\&A Contracts: Purposes, Types, Regulation, and Patterns of Practice (Harvard John M. Olin Discussion Paper Series Paper No. 825, Apr. 2015).

\section{Published Version}

http://www.law.harvard.edu/programs/olin_center/papers/pdf/Coates_825.pdf

\section{Permanent link}

http://nrs.harvard.edu/urn-3:HUL.InstRepos:17743076

\section{Terms of Use}

This article was downloaded from Harvard University's DASH repository, and is made available under the terms and conditions applicable to Other Posted Material, as set forth at http:// nrs.harvard.edu/urn-3:HUL.InstRepos:dash.current.terms-of-use\#LAA

\section{Share Your Story}

The Harvard community has made this article openly available.

Please share how this access benefits you. Submit a story.

\section{Accessibility}




\title{
HARVARD
}

JOHN M. OLIN CENTER FOR LAW, ECONOMICS, AND BUSINESS

\author{
M\&A CONTRACTS: \\ PURPOSES, TYPES, REGULATION, AND PATTERNS OF PRACTICE \\ John C. Coates IV \\ Research Handbook on Shareholder Power
}

Discussion Paper No. 825

$04 / 2015$

Harvard Law School

Cambridge, MA 02138

This paper can be downloaded without charge from:

The Harvard John M. Olin Discussion Paper Series: http://www.law.harvard.edu/programs/olin_center/

The Social Science Research Network Electronic Paper Collection: $\underline{\text { http://ssrn.com/abstract=2593866 }}$ 


\title{
M\&A Contracts:
}

\section{Purposes, Types, Regulation, and Patterns of Practice}

\author{
John C. Coates IV
}

First Draft: April 11, 2015

As used in this chapter, mergers and acquisitions (M\&A) consist of deliberate transfers of control and ownership of businesses organized in one or more corporations. ${ }^{2}$ M\&A transactions are governed by contracts, the focus of this chapter. M\&A contracts serve a typical set of goals, some common to other kinds of transactions, some distinct to M\&A. They are not "contracts of adhesion"3 - while full of "boilerplate,"4 are negotiated and at least partly tailored to a specific deal in a "bespoke" fashion by specialists. M\&A contracts are shaped by regulation of M\&A, by corporate law, finance, accounting and the business environment, and by fundamental economics of corporations, especially trade-offs between control and liquidity that influence patterns of ownership. As a result, M\&A contracts fall into distinct types, with standard sets of provisions, while varying substantially within type, by country, and over time.

Relative to their practical importance, compared to (say) fiduciary duties or hostile takeovers, M\&A contracts are understudied, are vastly more complex than can be analyzed in detail here, and change over time. As a result, this chapter of the Research Handbook on Mergers and Acquisitions has four goals. First, basic purposes of contracts generally and M\&A contracts in particular are reviewed, including an overview of the suite of contracts commonly needed in the course of an M\&A transaction. Second, the contents of core "deal contracts" in M\&A are described in general terms, by reference both to the standard organization and labels in the contracts themselves, and also to a functional typology derived from the purposes of deal contracts, illustrated by examples from high-profile deals and a representative sample of M\&A contracts involving U.S. targets. Third, ways that M\&A contracts for U.S. targets are shaped by ownership and regulation are summarized. Fourth, rigorous empirical studies of the contents and effects of M\&A contracts - which have grown rapidly in recent years, but

\footnotetext{
${ }^{1}$ John F. Cogan Professor of Law and Economics, Harvard Law School. Copyright John C. Coates IV; all rights reserved. Thanks for research assistance to David Acquay. For disclosure of financial interests potentially relevant to this chapter, see www.law.harvard.edu/faculty/COI/2014CoatesJohn.html.

2 Throughout, "corporations" is a stand-in for various types of business entities. Typically, M\&A transactions involve at least two and often three corporate parties: a buyer, a target, and (often) a seller/parent. In deals for public targets, there is no single "seller," but a large number of shareholders whose shares are converted into cash or other deal currency. Transactions that achieve similar economic goals - such as spin-offs, joint ventures, and recapitalizations - are distinct in practice and are not reviewed here.

${ }^{3}$ Rakoff 1983.

${ }^{4}$ See note 24 infra.
} 
remain focused on a small number of contract terms - are briefly summarized. The chapter concludes with a brief agenda for future research on M\&A contracts.

\section{The purposes of M\&A contracts}

\section{a. Purposes of contracts generally}

Before discussing M\&A contracts' particulars, it is worth reviewing the basic purposes of contracts generally. Kaplow and Shavell 2004 identify five economic reasons that exchanges can be socially valuable, arising from differences in (a) valuations; (b) risk preferences and risk-bearing capacities; (c) productive abilities, such as economies of scale or specialized skills arising from the division of labor; (d) complementarities of ownership or control of assets, giving rise to economies of scope; and (e) financing capabilities. Valuations can vary due to differences in raw preferences, information, and expectations. Finance, whether in the form of cash for debt or equity or some hybrid, is valuable whenever people with capital differ from those with business opportunities requiring investment. Risk sharing (i.e., insurance) can be valuable whenever people differ in their risk preferences, as altered by economies of scale in the form of diversification and pooling of risks. As discussed below, each of these functions is reflected in standard M\&A contracts.

Some exchanges - e.g., a purchase of a hamburger - can be accomplished in "spot" markets in which no "contract" (of a conventional written sort) is worth the effort. But other exchanges - particularly exchanges of complex packages of goods and services, such as businesses, or exchanges over time or after delay - are usefully memorialized and specified in writing. Memorialization aids memory and communicates contract terms to third parties, including courts or others charged with resolving contact disputes, ${ }^{5}$ and underwrites reputational consequences for breach. ${ }^{6}$ Written contracts comply with requirements for enforceability ${ }^{7}$ and provide legal benefits. ${ }^{8}$ In complex trades, specification can be more

\footnotetext{
${ }^{5}$ Disputes are common in the M\&A context. Coates $2012 \mathrm{~b}$ reports $60 \%$ of M\&A practitioners surveyed reported having had clients have a dispute arising out of indemnities and price adjustment clauses in M\&A contracts. Cf. Weintraub 1992 (in survey of corporate general counsels, a third reported their company having litigated disputes under contracts of any kind). See also Miller 2009a, 2009b (analyzing disputes over material adverse change clauses). Large M\&A transactions take months to complete, and M\&A contracts in deals involving risk- or control-sharing can have lifespans of a decade or more. For example, the author helped negotiate seven bound volumes of contracts and closing documents for the repossession of the Trump Shuttle by a lender group and a partial disposition of the equity of the airline to USAir, subject to ongoing options and control-sharing agreements between USAir and the lending group. These agreements continued to govern the business for ten years after the initial deal closed.

${ }^{6}$ Hill 2001 ("parties [to contracts] feel constrained by reputational and other extralegal forces within the complex contracting community").

${ }^{7}$ E.g., New York General Obligation Law \5-701; see also Uniform Commercial Code \ 2-201 (writing required for sales of goods involving \$500); cf. Johnston 1996 (finding strict application of $\ 2$ 2-201 to contracts between strangers, but not to contracts between parties with prior dealings).

${ }^{8}$ E.g., People ex rel. Spitzer v. Grasso, 861 N.Y.S.2d 627 (2008) (applying parol evidence rule to interpretation of employment contract following merger of non-profit into for-profit).
} 
important than memorialization: by writing terms down, parties clarify the exchange - not only to others, or their future selves, but also to their current selves. The act of writing (or reading a write-up of) what has been agreed commonly leads contracting parties to realize they have spoken incompletely, incorrectly, or incoherently. Writing allows for more precision and finer distinctions. People often use the same words to mean different things. Contract lawyers, often denigrated (even to themselves) as "scriveners," force a fuller second or third thinking through of what contract parties thought they had agreed.

\section{b. Purposes particular to M\&A contracts}

M\&A contracts serve the foregoing general purposes but also serve purposes unique or at least of heightened importance in the M\&A context. As discussed in Part II, they play a crucial role in specifying the terms of a deal, which are often complex, and for

communicating deal terms to agents and other third parties. M\&A contracts are sometimes ${ }^{9}$ legally required, and are always useful for the management of disputes, which are common, given the complex terms and lengthy duration of many M\&A deals. ${ }^{10}$

M\&A transactions are typically important - and worth the investment in a tailored and negotiated contract - because they represent a substantial investment for the buyer, a change of control and ownership (or even the "end of corporate life") for the target, and a significant transformation in the assets of the seller. They are also typically complex because the subject of the transaction is not simply a collection of assets but - by definition - control over a business. The variety of assets typically included in an M\&A deal include types of assets that raise complexities on their own: intellectual property, real estate, regulatory licenses. The transfer of this mix of tangible and intangible assets is typically coupled with changes in or transfers of contractual and non-contractual relationships with a variety of individuals, from shareholders, directors and managers to employees and agents, from customers and suppliers to lenders and regulators. M\&A transactions are also commonly significant for buyers because they require collateral or bundled financing transactions and changes in a buyer's capital structure, because they can change a buyer's post-deal control and governance, and because they often have a bigger impact on the operations and reputation of the buyer and its managers than other strategic investments.

\footnotetext{
${ }^{9}$ The statute of frauds would not apply to M\&A transactions if they do not include guarantees, direct transfers of real estate or "goods" (which they would not if structured as mergers or stock purchases), or last more than a year. Deals for targets with inventory that are structured as asset purchases would commonly trigger standard statutes of fraud, as would contracts with typical post-closing indemnities. In addition, some states, including the important business jurisdiction of New York, have expanded their statutes to requires a writing for any contract for services in negotiating or brokering a deal involving a "business opportunity, business, or interest therein..." New York General Obligation Law \5-701. Corporate statutes, see note 11 infra, would require an agreement for a deal structured as a merger, but not necessarily for a deal structured as a stock purchase. For an overview of commonly used deal structures, see Coates 2014.

10 See note 5 supra.
} 
M\&A contracts can be legally required for multiple reasons. Corporate statutes mandates that boards and shareholders approve mergers pursuant to written agreements or plans of merger. ${ }^{11}$ Securities laws commonly require disclosure of M\&A deal terms before shareholder approval or related investment decisions are made. ${ }^{12}$ Regulators routinely require submission of agreements before approving M\&A transactions. ${ }^{13}$ If control or ownership of the ongoing business is to vary from default corporate law, as is not unusual, then a contract altering the combined companies' ongoing governance (such as a shareholders agreement or set of proposed charter or bylaw amendments) may be required.

Beyond these requirements, M\&A contracts perform an essential communication and coordination function. A typical M\&A process involves planning, search, investigation, negotiation, processing, "closing" (i.e., completion of the basic deal), post-closing integration, services, and claims processing or dispute resolution. These tasks involve dozens if not hundreds or thousands of employees and agents of the target and the buyer. To best carry out their tasks, these individuals must be able to evaluate or understand the terms (actual or planned) of an M\&A deal to achieve its purposes, as set out in a contract.

\section{c. Preliminary, collateral and core $M \& A$ contracts}

A typical M\&A transaction involves not one but a suite of contracts. Preliminary to a deal, confidential information is typically shared, and negotiations or auction-like bidding are conducted, generating the need for confidentiality and exclusivity agreements, ${ }^{14}$ standstills, ${ }^{15}$ letters of intent, ${ }^{16}$ and joint defense agreements. Collateral to a deal, employment and other ongoing contractual arrangements must be adjusted, generating the need for employment and non-competition agreements. ${ }^{17}$ To accomplish a deal, legal requirements must be satisfied, typically by gathering and packaging information, providing it to regulators, shareholders or the public, and analyzed, generating the need both for detailed conditions and agreements concerning who is responsible for and how they will satisfy these requirements, and commonly for separate support agreements, voting

11 E.g., Del. Gen. Corp. L. \ 251.

12 E.g., Securities and Exchange Commission, Rule 145 (deeming merger vote to involve an offer and a sale of securities to be issued in the merger for purposes of the Securities Act of 1933).

${ }^{13}$ E.g., 12 U.S.C. $\int 1842$ (requiring approval of Federal Reserve Board before a company acquires control of a bank).

${ }^{14}$ Kirman 2008 (reviewing customary terms of such agreements in detail).

15 Id.; Sautter 2013a, b.

16 Schwartz and Scott 2007.

${ }^{17}$ Freund 2008 Chapter 11; see also Whitmore 1990 (analyzing case law in disputes over enforceability of noncompetition clauses); Wulf 2004 (finding evidence that executives of companies in "mergers of equals" obtain control and employment benefits in exchange for shareholder premia). Labor agreements may also need to be renegotiated as a result of M\&A transactions. 
agreements, lock-up option agreements, ${ }^{18}$ and affiliate letter agreements. Before financing an acquisition, banks and underwriters typically parties specify deal terms, to be reflected in financing agreements, including highly confident letters, commitment letters, sponsor guarantees, loan agreements, solvency opinions, and other agreements called for by the primary financing agreements. ${ }^{19}$

All of these contracts can be understood as "M\&A contracts," but they all also lead to or are required by the core M\&A contract, the "definitive" deal agreement. Because of the inherently complex nature of M\&A and the dynamic nature of the businesses being exchanged, contracts are particularly useful in specifying the basic terms of the deal: the parties, the "deal structure" (e.g., mergers, asset purchases, stock purchases, etc.) and the "deal currency" (e.g., cash, stock, debt, other contract rights, assets, etc.). In M\&A deals for divisions or units of larger businesses, or which are structured as asset purchases for other reasons, a contract will perform the essential task of specifying what is being transferred. In deals involving anything other than cash as consideration, the contract will specify how the consideration will be valued and transferred. Sometimes, contract specification can economize on corporate law by designating that whole companies to merge or have their stock acquired, but the contract can still play an essential role by controlling or conditioning deal terms on the changes over time, especially changes in the value or risk of the business. For example, contracts can make clear the extent to which the target owners can receive dividends or distributions while a deal is pending. To be completed, most deals require more work after contract signing, and M\&A contracts assist process management - specifying responsibilities and coordinating tasks to get the deal done. Exchanges ancillary to the basic deal - particularly risk sharing, control and information sharing, and service provision - by definition take time, and typically involve detailed specification, all as discussed more in Part II.c below.

Finally, as with contracts generally, M\&A contracts predictably generate disputes, ${ }^{20}$ even when they are well planned, negotiated and specified. Because disputes are often unavoidable, M\&A contracts contain a number of dispute management provisions ${ }^{21}$ that anticipate common disputes and attempt to resolve or manage them in advance, by guiding resolution if a dispute arises or a party fails to perform, or by discouraging litigation by

\footnotetext{
18 Such option agreements are economically similar but distinct from break fee provisions commonly found in definitive deal agreements. Coates and Subramanian 2000; see also Burch 2001 (reporting data on incidence and correlates of stock option lockup agreements); Davidoff and Sautter 2013 (discussing changes over time in use of deal protections, including stock option agreements).

${ }^{19}$ Rosof et al., 2013, 2014; Slaughter and May 2008; Reilly 2008; Sorkin and Swedenburg 2006; Nugent 2006; see also Davidoff 2009 (private equity deals in the 2008 crisis); Fang and Ivashina 2013 (financing by private equity); Ivashina and Sun (leveraged loan market); Axelson et al. 2012 (buyout financing).

${ }^{20}$ See note 5 supra.

${ }^{21}$ Eisenberg and Miller 2006, 2007; Coates 2012a; Cain and Davidoff 2012; Palia and Scott 2014.
} 
arming the counterparty with potential grounds for countersuits. ${ }^{22}$ Because M\&A parties can have preferences over dispute resolution that vary from the preferences of others subject to ordinary dispute resolution through the court system, arbitration or modified rules of procedure can be usefully included in M\&A contracts. Similarly, many default rules of contract, tort or property law may be usefully altered in the context of an M\&A contract in case a dispute involves those rules arises. ${ }^{23}$

\section{The contents of M\&A contracts}

With this overview of the purposes of M\&A contracts in mind, what specifically do the core "deal agreements" in M\&A transactions address? This question will be answered in two ways: a formal analysis of the contents of actual agreements, and a functional analysis that relates the formal categories of contract provisions to the purposes outlined in Part I. Each set of answers draws on recent examples of M\&A contracts from a representative sample of deals involving U.S. targets from to illustrate the points.

a. Constrained variation in boilerplate

Before reviewing the typical contents of M\&A contracts, a preliminary puzzle should be noted. How, on the one hand, can M\&A contracts are generally negotiated, but, on the other hand, have contents capable of being generally described and analyzed? The answer to the puzzle is that the bulk of the content of M\&A contracts can be fairly described as boilerplate ${ }^{24}$ exhibiting constrained variation. Only a small number of terms are truly dealspecific terms. ${ }^{25}$ That is, while M\&A contracts are negotiated, and so are not purely form contracts, most of their contents - $90 \%$ would be a conservative estimate - of the "negotiated" terms are "negotiated" between the parties by agreeing upon a term from a closed subset of standard variants. At the same time, a large fraction of the terms - a speculative guess would be roughly $50 \%$ - can and do vary within a typical sample of M\&A contracts. In other words, for any given term, the alternatives are few in number, but for any given contract, with hundreds of terms to be chosen, even a small number of alternatives can in combination produce enormous (if constrained) variation.

\footnotetext{
${ }^{22}$ Hill 2008 (complex agreements "provides each party with grounds to bring a lawsuit [so] if one party sues, the other party will virtually always have grounds to countersue").

${ }^{23}$ Coates 2012c notes that all of the indemnification periods in a sample of M\&A contracts from 2007-08 were shorter than the default statutes of limitations under applicable law. Korobkin 1998 reports experimental evidence showing that default rules exert a pull on contracting parties, which he attributes to status quo bias.

${ }^{24}$ For analysis of boilerplate generally, see Kahan and Klausner 1997; see also Hill 2013.

25 As an example of a deal-specific term, consider the purchase price specified in the Stock Purchase Agreement among Freeport-McMoRan Copper \& Gold Inc., Phelps Dodge Corporation, and other sellers, and General Cable. The price was to be set by a formula equal to $\$ 735$ million plus a "Closing Netting Amount," to consist of seven specific adjustments, including a deduction for the lesser of $\$ 5$ million or the "Friable Asbestos Remediation Estimate," to be estimated based on a survey of specified companies in the deal by an environmental consultant to be chosen by mutual agreement within fifteen days of the signing.
} 
The fact that negotiations are so constrained has over time given rise increasingly among practitioners to the use of "market" norms for the great majority of terms in a given M\&A contract. "What is market?" is a standard question lawyers ask to evaluate a proposed agreement's terms, meaning, what are the standard ways that the clause in question has been drafted by others in prior deals? The answer will vary by deal context, for reasons discussed in Part III, and others. The answer also tends to change over time in response to legal and business shocks to general market expectations, but sources of data on market norms used with increasing frequency are the "deal points" studies by the American Bar Association and data reported regularly by organizations such as the Practical Law Company. ${ }^{26}$ Over time, terms tend to accrete, so M\&A contracts are longer and more detailed today than in the past. $^{27}$

As an example of how substantial variation in M\&A contract terms can co-exist with market norms constraining such variation, consider "material adverse change" clauses, commonly called MACs, or "material adverse effect" or MAE clauses. ${ }^{28}$ Substantial variation exists in both the language of the clauses, and also in the legal functions they perform in the contract. MAC clauses can cover future events ("prospects") as well as (more commonly) past events ("results of operation"), and be absolute with respect to a given party, or (more commonly) relative to changes in economic, legal, or industry benchmarks, with such benchmarking typically achieved by a number of (relatively) standardized "exclusions" of general changes from what is counted as a MAC, resulting in the MAC only being triggered by firm-specific events, ${ }^{29}$ and to exclude changes induced by the deal itself. ${ }^{30}$ Just as important, but less appreciated among researchers, the uses of MAC clauses vary as much as do their terms. They can be used to qualify representations, covenants, or conditions; as part of a separate MAC condition; and to trigger termination rights. Such clauses play only a limited role, by contrast, in the core deal structure and deal currency provisions of an agreement, or in indemnification provisions.

\footnotetext{
${ }^{26}$ See generally apps.americanbar.org/dch/committee.cfm?com=CL560000 and us.practicallaw.com.

${ }^{27}$ An M\&A contract I worked on in practice in 1995 was the agreement between IBM (represented by Cravath Swaine \& Moore) and Lotus Development (represented by Wachtell Lipton Rosen \& Katz). tinyurl.com/195xgn4. That contract provided for a cash tender offer followed by a cash merger for $100 \%$ of Lotus's stock. Lotus was a significant company, and the deal was among the largest completed that year. The agreement contained 21,675 words. In 2014, a similarly structured deal - the acquisition of Sapient by Publicis Group - also negotiated by Cravath and Wachtell - contained 39,424 words. tinyurl.com/m5bpyxe. The difference of 17,749 words is an increase of over $80 \%$, or $4 \%$ per year over each of the intervening 20 years. This comparison is based on a single matched pair of contracts, and more research would be needed to verify that a similar increase has occurred across all types of M\&A contracts, but a quick review of the pair of agreements nothing unusual about either deal that would account for the difference, and a large increase can be found in each article, including increases of more than $10 \%$ in all but recitals and conditions, consistent with overall accretion over time.

${ }^{28}$ Talley 2009; Miller 2009a; Miller 2009b; Denis and Macias 2013; Gilson and Schwartz 2005; DeChiara et al. 2007.

${ }^{29}$ Talley 2009; Denis and Macias 2013.

${ }^{30}$ Miller 2009a.
} 
To illustrate this constrained variation in boilerplate with data, from a representative sample of 120 M\&A deals involving U.S. targets from 2007 and 2008, ${ }^{31}$ MACs were found in every contract, being used between two and 52 times, averaging 24 usages per agreement. The vast majority (over 90\%) of usages were not explicit conditions or termination provisions as commonly assumed by non-lawyers who have read about MACs in the business press but instead were qualifications to representations, typically reducing the ability of the buyer to get out of a deal based on the falsity of the qualified representation. Another normal usage was as qualifiers to the "bring-down" clauses, ${ }^{32}$ which are standard conditions to one party's obligations to complete the deal requiring that the other party's representations have been true when made and remain true through the closing of the deal, and that the other party's covenants have been met. ${ }^{33}$ MACs were much less common in covenants and indemnities $(\mathrm{p}<.001)$.

Some of the observed variation in MAC usage is readily explicable by reference to observable features of the contracting environment, such as industry and ownership. Contracts for public company targets in the Representative US Target Sample relied much more heavily on MACs - public target contracts contained an average of 30 MAC usages, versus only 18 for private targets $(\mathrm{p}<.001)$, consistent with representations and related risksharing being less important in public target deals, ${ }^{34}$ as discussed more in Part III, making generous exceptions (accomplished through MAC qualifiers) more common. ${ }^{35}$ Much of the variation, however, remains a function of deal-specific factors not readily reducible to simple explanations.

b. Conventional organization of and labels in M\&A contracts

A typical M\&A contract is formally organized into a number of "articles," each containing a number of "sections." In a common sequence, articles cover (1) parties and recitals, (2) price, currency and structure, (3) representations and warranties, ${ }^{36}$ (4) covenants, (5) conditions, (6) termination provisions (“outs”), (7) indemnification, (8) tax, (9) defined

\footnotetext{
${ }^{31}$ See Coates 2010 and Coates 2012a for a description of this sample. Throughout this chapter, this sample will be referred to as the Representative US Target Sample.

${ }^{32}$ For examples, see sections 6.02(a) and 6.03(a) of the agreement and plan of merger contained as Exhibit I to the proxy statement available at tinyurl.com/ouh5axo.

33 This legal function means that even if MACs are not formally "in" the conditions section of a contract, their presence in the representations will be indirectly incorporated into the bring-down condition, and even if they are not in the covenants section, they will be indirectly incorporated through the bring-down condition, which will often be a more important remedy for breach of a given covenant than conventional expectations damages.

34 See Coates 2010.

35 See also Gilson and Schwartz and Denis and Macias.

${ }^{36}$ Formally, a representation is a statement of fact, including actions that can be so interpreted, such as giving someone a set of financial statements, whereas a warranty is a promise that a representation is true and reliable. M\&A contracts do not typically distinguish between them, but include them together without identification.
} 
terms, ${ }^{37}$ and (10) miscellaneous clauses. This sequence reflects a sensible practical set of concerns: it puts up front key business terms of most interest to business clients, followed by terms typically requiring one or both parties to gather responsive information. Next come covenants covering conduct prior to closing, then a list of conditions necessary to get to closing. Termination - not a hoped-for outcome - comes late, followed or sometimes preceded by obligations relevant only after closing, such as tax and indemnification, rounded out by miscellaneous provisions only lawyers could like. Table 1 summarizes, with data on the average length of these formal articles in the Representative US Target Sample. (Differences between public and private target contracts are discussed in Part III.)

[Insert Table 1 About Here]

Recitals are generally non-operative, guiding interpretation and memory, and take up only $1 \%$ of words in the contract, on average, but can contain important definitions that do play an operative legal role throughout the contract. ${ }^{38}$ Core deal terms are next - they take up only $11 \%$ of words in the contract, but are typically the focus of intense negotiation and deal-specific variation, particularly if complex terms are included. Complex pricing terms include price adjustments, ${ }^{39}$ earn-outs, ${ }^{40}$ cash elections, ${ }^{41}$ collars, ${ }^{42}$ and ticking fees. ${ }^{43}$ Examples are discussed below. Also typically addressed in the core deal terms are mechanisms to "support" enforceability of payment or repayment, such as holdbacks and escrows. $^{44}$

Representations take up the bulk of an agreement (39\% of words). Despite this - or perhaps because of their imposing and detailed bulk - few sustained studies of representations have been published. This part of the contract generally consists of factual statements about past facts about, or promises ("warranties") about the future of, a party and its business. Where a contract includes an indemnification (discussed below), it will typically be linked to the representations, which are in turn customarily supplemented (or qualified) by "disclosure schedules" attached to the contract, which can contain general

\footnotetext{
${ }^{37}$ Some M\&A contracts omit separate definitions sections, instead distributing defined terms throughout, and then sometimes including an index of defined terms instead. See, e.g., tinyurl.com/195xgn4 and tinyurl.com/m5bpyxe.

${ }^{38}$ E.g., 1.usa.gov/1roU57G at iv (defining "business" in recitals, using "business" throughout contract).

${ }^{39}$ Coates 2012b; Coates 2012c; Freeland and Burnett 2009; Tresnowski 2009.

40 Gilson 1984; Ragozzino and Reuer 2009; Bruner 2004; Datar, et al. 2001; Kohers and Ang 2000; Goldberg 2006; Cain et al. 2011; Quinn 2012; see text accompany notes 85 infra.

${ }^{41}$ Chinn et al. 1995. For an example, see section 3.01 of tinyurl.com/16rek7f.

${ }^{42}$ Chinn et al. 1995; Freund 1998 Chapter 6; Officer 2004. For an example, see section 3.01 of tinyurl.com/16rek $7 \mathrm{f}$.

43 Tucker and Yingling 2009.

44 Coates 2012b and Coates 2012c.
} 
information or present specific and detailed sets of information (e.g., lists of employees holding stock options). Throughout, qualifications are an important type of variation, having both subjective (reasonableness, materiality, knowledge ${ }^{45}$ ) and objective (specified de minimis exceptions or thresholds).

Target representations are (on average) a larger component of M\&A contracts than those from the buyer, ${ }^{46}$ taking up $30 \%$ and $9 \%$ of the words, respectively, and overall they are more extensive than typical in (for example) lending agreements. "Fundamental" representations consist of those needed to insure the buyer obtains the basic legal package entitling it to control over the assets it expect, and for a target to insure its owners get the price they expect. ${ }^{47}$ In addition, a few representations are particularly value-relevant: for buyers, they cover the target's financial statements and the absence of material changes since those statements, with inventory and liabilities often being covered separately. Also valuerelevant is the target representation about related party transactions. In cash deals, targets will customarily obtain a financing representation, and in stock deals, targets will seek representations about buyer financial statements and the absence of changes. Both buyers and targets seek information about relevant litigation. Targets will make many other representations addressing specific topics. ${ }^{48}$ Finally, a representation that can be a focal point for negotiations is the "10b-5 rep" - so-called because it tracks SEC Rule 10b-5 in content and covers misleading omissions - and/or a "full disclosure" representation, which addresses all material omissions. ${ }^{49}$ Buyers may be asked to represent that they do not know of misrepresentations by the target (anti-sandbagging clauses ${ }^{50}$ ), or that they have not relied on extra-contractual statements (non-reliance clauses), and vice versa.

Covenants are the second-biggest part of the agreement. In M\&A contracts, covenants come in several places: (a) basic promises to fulfill the deal are in the deal terms section, (b) negative or "interim" or "operating" covenants which limit the target's ability to

45 The ABA Private Targets Deal Points Study for 2009 reports that in a sample of 106 private US target deals in $2008,25 \%$ of sample contracts limited knowledge to "actual" acknowledge only, while $68 \%$ incorporated constructive knowledge (e.g., knowledge "after due inquiry") for at least some representations.

${ }^{46}$ An exception to this rule of thumb is that in mergers of equals or near-equals involving stock currency, representations are often identical for both parties. In deals involving stock as currency, buyers make more representations than in cash deals: in the sample analyzed in Table 1, the ratio of target reps to buyer reps (in words) is $5 x$ in all cash deals, but only $2 x$ in all stock deals and $3 x$ in deals involving a mix of consideration.

${ }^{47}$ These typically address matters such as organization and subsidiaries, capitalization, authority for the transaction, and conflicts that the transaction may create with existing commitments and contracts.

${ }^{48}$ These typically include violations of law, contract compliance, taxes, employee benefits and labor matters, intellectual property, insurance, properties and facilities, and environmental risks. Material contracts of the target are often scheduled in response to a representation.

49 The ABA Private Targets Deal Points Study for 2009 reports that in a sample of 106 private US target deals in $2008,67 \%$ of deals included a $10 \mathrm{~b}-5$ representation and $9 \%$ included both a $10 \mathrm{~b}-5$ representation and a full disclosure representation.

50 Whitehead 2011. 
changes it practices materially prior to the closing, (c) "processing" covenants that specify the parties' respective obligations to take specific actions to complete the deal, (d) postclosing covenants, including servicing, director and officer indemnification and employment, employee benefit commitments, and non-competition, as well as covenants addressing tax and indemnification obligations (which are generally contained in a separate article). Indemnities and tax covenants are important risk-sharing or burden-allocating devices discussed more in Part II.c below. Together, interim, processing and nontax/indemnity post-closing covenants take up $20 \%$ of words in sample contracts, with indemnification taking up another $4 \%$, and tax covenants another $2 \%$.

Foremost among interim covenants are those barring ("no-shops") or limiting ("goshops") solicitation, ${ }^{11}$ facilitation ("no-helps"), negotiation ("no-talks") or acceptance of alternative transactions that would interfere with the deal under the contract, subject in the case of public targets to exceptions required (as discussed more below) by fiduciary duties of target directors, which are further subject to detailed clauses conditioning or limiting the exceptions, such as "match rights." 52 Other operating covenants are similar to negative covenants in loan agreements, and bar unusual risk-increasing actions like unusual asset acquisitions or encumbrances, dividend increases, and capital expenditures. M\&A contracts also typically bar risk-reducing but ownership-diluting actions like stock issuances, option grants, and debt-for-equity exchanges. They also more specifically address value-relevant changes, such as new material contracts, changes in accounting policies, settlement of lawsuits. Processing covenants come with a variety of standard qualifications (e.g., "best efforts," "reasonable efforts," etc.) and are particularly important in deals facing completion risks arising out of antitrust or other regulation, financing, or approval requirements. Variants require specified parties to spend money, sell assets, extend the deal, increase the deal price, or do whatever is necessary ("hell or high water" clause) to complete the deal (at all or by a set date).

Conditions and termination provisions take up relatively less space $-5 \%$ and $3 \%$ respectively - but are generally more important than any given representation or interim covenant, because they can result in the deal dying altogether. ${ }^{53}$ Termination provisions include a standard minimum set - a "drop-dead date" allowing either party to terminate if the deal has not closed by that date, a mutual consent "out," and an "out" if the other party is in non-curable breach (or material breach that goes uncured for some set time) or some

\footnotetext{
51 Balz 2003; Subramanian 2008; Sautter 2008.

52 Davidoff 2013; Quinn 2011; Subramanian 2005, 2008.

53 Conditions are typically broken into three types: mutual conditions, buyer conditions, and target conditions. Mutual conditions are typically legal requirements (e.g., antitrust clearance, shareholder approval, absence of injunctions), whereas buyer and target conditions consist of bring-down clauses mentioned above, as well as officers' certificates tracking those clauses. In private target deals, many more conditions are not unusual, including requirements to obtain investment banker fairness opinions, legal opinions, "comfort letters" from accountants, and other documents commonly delivered at the closing at the deal.
} 
event has occurred that would make a condition incapable of being satisfied prior to the drop-dead date. Beyond these, many agreements contain more specific "outs," particularly relating to target fiduciary duties, financing, or antitrust or other regulatory requirements. Termination provisions also include important fee requirements contingent on specified triggers leading to termination - "break fees" and "reverse break fees."

Towards the end come defined terms, which take up $9 \%$ of the words. ${ }^{55}$ Two definitional "tricks" that give lawyers a bad reputation are (a) definitions sections are not always comprehensive - many definitions are found elsewhere in the contract, and are not even cross-referenced in the definitional section, as would be best drafting practice, and (b) some defined terms are not given capitalized letters, so that specially defined usages may not be obviously identified as such throughout the contract, requiring (in theory) every user to read the entire contract to fully understand it. Last come "miscellaneous" provisions, which round out the last $6 \%$ of the words in the Representative US Target Sample. ${ }^{56}$

\section{c. Functional categories of contents of M\&A contracts}

A more functional way to analyze the contents of M\&A contracts is by reference to their purposes, sketched in Part I.c above: specification, risk sharing, process management, control and information sharing, service provision, and dispute management. As will be noted, each of these functions is performed by different formal parts of an M\&A contract, sometimes in an integrated fashion (as when representations are the basis for an indemnity, and rely on defined terms), sometimes in separate ways (as when negative covenants forbid acts that are also addressed by representations coupled with a bring-down condition). The interwoven, multiply if partially redundant set of functions makes M\&A contracts a challenging task to draft, negotiate and interpret. Throughout this section, the focus is on functional explanations derived from narrowly framed economic analysis of the transactions,

\footnotetext{
54 On break fees, see Coates and Subramanian 2000; Bates and Lemmon 2003; Officer 2003; Boone and Mulherin 2007; Andre et al. 2007; Coates 2011. On reverse break fees, see Davidoff 2005; Tucker and Yingling 2008; Afsharipour 2010; Reverse Break-Up Fees and Specific Performance: A Survey of Remedies in Public Deals (Practical Law Company 2010); Quinn 2010. Such fees are different than liquidated damages clauses, which represent contractually agreed remedies for breach, as opposed to termination. Cf. Swett 1999.

${ }^{5}$ Definition sections can be found in some contracts earlier, at the outset of the agreement. E.g., 1.usa.gov/1oShgDg (definitional section is first article of agreement).

56 These are mostly "legal" provisions common to many business contracts: integration clauses, making clear that the parol evidence rule will should apply, and severability clauses, making it clear that the unenforceability of one clause should not lead a court to decline to enforce other clauses. Also in the "miscellaneous" category are clauses designating choice of law and choice of forum, specifying remedies, such as specific performance, and waiving procedural rights, such as to juries, punitive damages or consequential damages. Such clauses also address third-party beneficiaries and common interpretive issues (plural vs. singular, rejecting interpretations based on who drafted the contract), allow for signing in counterparts, and attempt to impose requirements on waivers and amendments (the latter are commonly included in contract articles addressing termination).
} 
and other explanations for the contents of $\mathrm{M} \& \mathrm{~A}$ contracts ${ }^{57}$ are neglected, not because they are unimportant, but because they are less directly useful in understanding what parties to M\&A deals are fairly understood as attempting to achieve through M\&A contracts.

\section{i. Specification of structure}

Specification is a purpose served in many parts of an M\&A contract, but is most important for the core elements of the business deal. Specification of deal structure is important: the choices of one-step stock purchase, asset purchase, or merger, or multi-step structure, and of precisely which corporate entities will be involved and how, will determine what assets and liabilities the buyer will get. Except for asset purchases or deals involving multiple corporate sellers, specification of structure is generally simple and often set out in the recitals, in whole or in part. Morgan Stanley's 1997 "merger of equals" with Dean Witter was structured as a direct merger; ${ }^{58}$ AT\&T's attempted 2011 acquisition of T-Mobile was to be a simple purchase of the stock of a second-tier subsidiary of Deutsche Telekom, as reflected in the "deal" article of the primary deal contract, which cross-referenced back to the recitals. ${ }^{59}$ AT\&T's 2014 agreement to buy DirecTV is structured as a forward triangular merger; ${ }^{60}$ and Comcast's 2014 agreement to buy Time Warner Cable is structured as a reverse triangular merger. ${ }^{61}$

\section{ii. Specification of business}

Beyond structure, specification in core deal terms is particularly important if the deal includes one of two common if not universal features: partial acquisitions, commonly structured as asset purchases; or complex pricing. ${ }^{62}$ First, specification is a crucial and time-consuming task if the deal consists of a purchase of a business that has not been a stand-alone legal entity, but instead has been a division or business unit of a larger company,

57 These include agency costs affecting lawyers and other participants in M\&A, such as shirking or grandstanding, as well as behavior economics, and transaction cost-based explanations such as path dependence or herding. For examples of studies finding evidence consistent with such explanations, see, e.g., Coates 2012a, 2013a.

58 tinyurl.com/ouh5axo at I-1.

59 1.usa.gov/1oShgDg at 16.

60 1.usa.gov/1nApnqH at 1.

${ }^{61} 1$.usa.gov/1mQipKJ at 13 , cross-referencing back to recitals at 1.

62 A fourth role for specification arises in those deals having complex tax effects. In most deals, this role is unimportant: the deals are either structured to qualify as tax-deferred reorganizations, having no immediate tax implications, or are simple cash-outs of shareholders, with straightforward tax effects, including a step-up in basis for the acquirer. Where the deal is a partial acquisition and the seller/parent with an ongoing business, however, the tax consequences of an M\&A transaction can become significantly more complex. M\&A contracts commonly contain an article devoted to specifying how the parties will divide up pre- and post-deal tax liabilities and assets, state the parties' tax-related intentions for how the transaction will be treated under tax law, and set forth special tax indemnities, record-keeping, reporting and cooperation obligations. Sometimes these provision simply track default tax law, but they sometimes significantly alter tax-related entitlements or burdens as between the parties. An example can be found in Article VI of tinyurl.com/miqlwmx. 
or a separate legal entity that derives necessary services or functions from related entities, as in a divisional acquisition ${ }^{63}$ or divisional buyout. ${ }^{64}$ Such partial acquisitions require "business specification" - that is, a legal description of the business to be purchased, identifying the assets to be included or excluded, and liabilities to be assumed or retained. If (as common) a partial acquisition is structured as an asset purchase, ${ }^{65}$ business specification will be reflected directly in contract itself, and will take up much of price and terms articles of the contract, and also be reflected crucially in defined terms, and often cross-reference schedules attached to the contract. ${ }^{66}$

Despite efforts to use contracts to accomplish business specification, contract drafters commonly realize that they will not have fully succeeded in the task. ${ }^{67}$ In anticipation of these possibilities, it is common for M\&A contracts to contain "further assurances" or cooperation covenants that require each party to "take all necessary action" as "reasonably requested" by the other to accomplish the goals of the overall contract, ${ }^{68}$ and at least where the seller is an ongoing company, M\&A contracts not only achieve a deal, but also set up a collateral ongoing relationship between a seller/parent and buyer.

\footnotetext{
63 ABN AMRO's sale of its U.S. operations to Bank of America in 2007 is an example; for the contract, see tinyurl.com/nlfu6c3.
}

64 TPG's 2002 buyout of Burger King, which was a division of Diageo, is an example. Carliss Y. Baldwin and James W. Quinn, The Auction for Burger King, Harvard Business School Case No. 9-906-012 (Rev. Oct. 10 , 2012).

65 An example of a partial acquisition structured as an asset purchase is the May 2007 purchase by iStar Financial of Fremont Investment's commercial real estate mortgage lending business. 1.usa.gov/1 roU57G at iv. The contract defined the "Business" being sold in very general terms, as "the commercial real estate mortgage lending business" of Fremont and "various affiliates" at "various locations in the United States." To avoid disputes that would likely accompany such a general definition, the contract was more specific in Article I (definitions) and Article II (purchase and sale of loans and other assets, assumption of liabilities). For example, the contract listed the assets to be acquired as consisting of outstanding loans owned by Fremont as of the date of the agreement, along with scheduled real estate previously acquired through foreclosure by Fremont, other property acquired through repossession, scheduled leased real property, fixtures and equipment and similar tangible property "used solely in connection with the Business," books and records relating to the Business" and so on. The contract defines several categories of "excluded assets," including artwork, loans originated after the date of the agreement, scheduled leases, and assets related to "benefit plans," as separately defined. The contract was similarly specific about how the parties would divide the liabilities of the target.

${ }^{66}$ In a partial acquisition structured as a merger or stock purchase, business specification may be found instead in related intercompany documents (i.e., distributions or contributions) reflecting the creation of the new or newly restructured entity in advance of the deal. In other partial acquisitions the seller may convey ownership of an entire legal entity, but then buy back specified assets in conjunction with the overall deal. As an example, see section 6.13 of tinyurl.com/nlfu6c3 (covenant requiring seller to transfer specified subsidiary and its business from the target to the seller or an affiliate).

${ }^{67}$ There will be assets or liabilities that they have misallocated, given the goals of the parties, or there will be assets or liabilities that are not captured by the attempted specification, or which are ambiguously reflected. Alternatively, third-party consents needed to transfer assets or liabilities may not be forthcoming, resulting in the seller retaining assets useful in the post-deal business, and potentially making ongoing sub-service provision desirable.

68 As examples, see section 8.4 of tinyurl.com/mjqlwmx and section 6.10 of tinyurl.com/nlfu6c3. 


\section{iii. Specification of price}

Another reason that specification can be an important purpose of an M\&A contract is if the deal includes complex or unusual price or deal currency terms - i.e., anything other than a simple fixed cash price or exchange ratio - or a significant form of explicit price-relevant risk sharing. Examples of complex "price specification" includes formal price adjustments, ${ }^{69}$ earn-outs, ${ }^{70}$ and collars ${ }^{71}$ - that is, a formula in a deal involving stock currency that allows for the exchange ratio to float, subject to a cap and floor. Complexity also arises if target shareholders can choose what type of deal currency to accept (cash or stock), ${ }^{72}$ particularly if the buyer seeks to constrain that choice, again making specification important. Price terms often make use of their own specially defined terms and include their own specially identified conditions. Even more complexity can be introduced in deals where control or ownership will be shared over time.

\section{iv. Risk sharing and risk allocation}

Closely related to price specification is the risk-sharing function of M\&A contracts. Indeed, price adjustment and earn-out clauses are often as much about allocating risk in incentiveand information-compatible ways as it is about simply specifying the price to be paid. A similar but distinctive contractual means for M\&A participants to allocate risk is performed by indemnity clauses, which are typically linked to representations. Typically, indemnities are elaborately designed to reflect many of the economically equivalent functions of insurance contracts - deductibles (or "baskets"), caps, co-insurance, claims periods, and claims handling procedures - and often override (or attempt to override) default laws of contract, tort, property or procedure that would otherwise apply. ${ }^{73}$ In some contracts, for example, buyers insist on pro-sandbagging clauses giving them the right to indemnification for

\footnotetext{
${ }^{69}$ An example of modestly complex pricing can be found in the $\$ 2$ billion April 2007 purchase by Quest Diagnostics of Ameripath, Inc. tinyurl.com/pju832n. The contract for that deal included a price adjustment clause with text that takes up roughly half a page, used two defined terms (Balance Sheet and Specified Cash), and adjusted the price based solely on changes in the target's cash balances. A more complex pricing formula can be found in the contract for the $\$ 213$ million acquisition by Coleman Cable Inc. of Copperfield LLC in March 2007. tinyurl.com/lfvpd32. That contract's price adjustment clause took up more than two pages of bespoke text, not counting exhibits cross-referenced and incorporated into the contract, used more than a dozen specially defined terms, and built in adjustments based on working capital, employee bonuses, debt, transaction expenses, and environmental liabilities.

70 An example of earn-out can be found in the $\$ 260$ million November 2007 merger of LogistiCare, Inc. into Providence Services Corp. The merger agreement (available at tinyurl.com/nsbd4gf) provided for a contingent post-closing payment, capped at $\$ 40$ million, equal to nine times the increase in 2008 adjusted earnings before interest taxes, depreciation and amortization (EBITDA) and 110\% of 2007 adjusted EBITDA, which was carefully defined by reference to the target's audited financial statements, with several detailed adjustments, and could be paid in shares at the option of the sellers, subject to specified conditions that differed from the conditions to the overall deal.

${ }^{71}$ For an example, see id.

${ }^{72}$ For an example, see section 3.01 of tinyurl.com/16rek7f.

73 See Coates 2012c.
} 
breaches of representations even when they knew they were false at the time made (and hence did not rely upon them). ${ }^{74}$ Representations also play a risk-sharing role, even apart from a contractual indemnity, as they permit the parties to allocate between themselves the risk that value-relevant facts turn out to be other than believed. MACs, discussed above, can also serve to allocate risk, although because of the many and increasing exceptions to MACs, they may be more properly understood as serving an information-forcing function, as with representations generally.

Covenants also serve risk-sharing functions. Negative covenants impose the risk of changes in the business environment on the target, while exceptions to those covenants (particularly in a fixed-price deal) shift risk to the buyer. Conditions are powerful risk-allocating devices - they permit buyers to use the "self-help" remedy of refusing to close a deal if the conditions are not satisfied. Coupled with processing covenants, conditions can also be written to make clear that buyers may not refuse to close despite certain risks affecting the value of the deal occurring or not occurring, such as failure to obtain financing due to shocks to the financing environment, unexpected litigation, or unexpected realizations of regulatory risk during an antitrust review.

\section{v. Process management}

Deals take time and effort from multiple parties. To coordinate this effort (and, as just noted, to allocate risks associated with the effort), M\&A contracts perform a process management function. This function is reflected in the conditions - which set out the steps that must be taken before the parties are obliged to close - as well as in the termination section, which typically sets a "hard stop" on how long the process can continue before the parties can walk away. Most process management terms are in the covenants, which include general "efforts" clauses obliging the parties to use varying degrees of efforts to complete the deal, ${ }^{75}$ as well as more specific affirmative covenants requiring them to take specified steps, sometimes by specified dates, to achieve various necessary goals to permit the deal to close, or to provide the value the parties seek from the deal. These include scheduling and holding shareholder meetings, making regulatory filings, obtaining regulatory clearances, registering and listing securities (so as to make them liquid), obtaining financing, obtaining third-party approvals or modifications (or, alternatively, to repay or refinance debt contracts that would prohibit the deal). The covenants can be absolute, qualified or conditional, variations that effectively allocate different levels of risk on the responsible party to expend funds or be at risk of breach of the contract for failing to fulfill the relevant obligation, or in some cases to pay specified fees (break fees, reverse break fees or ticking fees). Also common are clauses specifying how rapidly after conditions are satisfied the closing is occur, and what documents are to delivered at the closing. No-shop and related clauses can also be

\footnotetext{
${ }^{74}$ See Whitehead 2011.

${ }^{75}$ For an example of a dispute over such clauses, see US Airways Group, Inc. v. British Airways PLC, 989 F. Supp. 482 (S.D.N.Y. 1997).
} 
understood as part of the process management function of a deal contract, as they typically set up clear notice and waiting period requirements, delineate when and how targets can accept superior bids, and sometimes provide buyers with match rights.

\section{vi. Control and information sharing}

Another distinct function provided by M\&A contracts is to specify how the parties will share control and information, at signing, between signing and closing, and in some deals after the deal closes. Nearly all M\&A contracts address moral hazard by containing interim covenants, as noted above, and address asymmetric information and improve pricing by setting forth factual representations, but both covenants and representations also reinforce the other's more obvious function. Negative covenants serve an information-forcing function because the negotiation process typically involves the buyer proposing tight restrictions and the target having to ask and explain the reasons for exceptions.

Representations generally concern past and knowable facts, but also implicitly affect control because they are typically "brought down" to closing as a condition to the other party's obligations to close, and so function similarly to interim covenants. In private target deals, representations also customarily are linked to indemnities, and sometimes address unknowable facts, or make promises about facts in the future (hence, "representations and warranties" is the typical formal description ${ }^{76}$ ), giving them a risk-allocation function. In private target deals, representations are also typically tied to detailed schedules, containing extensive information that the buyer can use in planning for integration as well as to firm up pricing.

A deal contract typically gives the buyer (and sometimes the target) rights to access and due diligence information (subject to antitrust law restrictions), which can be an important means for a buyer to assure itself about risks that it could not investigate prior to signing, and interacts with closing conditions and termination rights to insure that the target will have good ex ante incentives to disclose value-relevant information to the buyer. M\&A deals are also typically high profile, and the parties benefit from coordinating public relations, investor relations and employee relations communications about the deal. In mergers of equals, it is common for the contract to specify what are known as "social issues" - including how the initial board composition of the combined company will be chosen, and sometimes attempting to specify officer choices. ${ }^{77}$ In acquisitions of less than $100 \%$ of the stock of the target, and less obviously whenever there is an earn-out included as part of the deal consideration, there is generally a need for providing at least some ongoing control rights to the seller or the target shareholders. ${ }^{78}$ Finally, where the contract provides for ongoing risk sharing after the closing, the price adjustment or indemnity provisions will typically govern

\footnotetext{
${ }^{76}$ See note 36 supra.

${ }^{77}$ For an example, see section 1.06 of tinyurl.com/ouh5axo (establishing initial board of directors of combined Morgan Stanley and Dean Witter after their 1997 merger).

${ }^{78}$ For an example, see section 2.5(e) of tinyurl.com/nsbd4gf.
} 
how risks are realized and managed, with some sharing of control rights, and if there are multiple owners of the target, a contract will commonly provide for the appointment of a shareholder representative to coordinate and act as a quasi-governing agent in working (or disputing) with the buyer after closing. ${ }^{79}$

vii. Service provision

Collateral to the main deal, M\&A transactions commonly require the parties to provide services to each other. In partial acquisitions, the seller will typically retain operations and assets that were used by the target - and thus will continue to be useful after the closing, until the buyer can replace them, which may take longer than the main deal. Such services commonly include information systems, as well as specialized functions performed by key employees. While such services can be provided for in a separate agreement, ${ }^{80}$ they are also sometimes included in a main deal agreement.

viii. Dispute resolution

A final function performed by M\&A contracts is to manage disputes should they emerge, as is common. Many of the provisions in the "miscellaneous" article of a deal agreement address dispute management, as detailed in Coates 2012a, but so too do alternative dispute resolution provisions commonly included in price adjustment clauses, as well as many of the procedural aspects of indemnity clauses. Efforts to minimize costs of enforcing other contract provisions through hold backs, escrows and seller financing, and through some of the control sharing elements sketched above, also are fairly understood as efforts to manage ther resolution of disputes. Termination rights and conditions, too, can be fairly viewed as establishing entitlements that can give one or both parties more power to resolve particular disputes in their own favor. Finally, throughout a contract, there are many interpretive and qualifying phrases that play important roles in managing disputes. Examples include the qualifying use of MAC clauses noted above, the many exceptions in those clauses, ${ }^{81}$ as well as words such as "reasonable," phrases requiring one party's contract-created veto over an act to be "not be unreasonably withheld," and scienter requirements putting a evidentiary burden on a party seeking damages based on a false representation or covenant breach.

III. The effects of ownership and regulation on M\&A contracts

M\&A contracts, unlike consumer contracts, are not heavily regulated in a direct fashion, although they do respond to background rules of a variety of bodies of law. Most basically, M\&A contracts contain clear conditions that respond to (often essentially restating) requirements in background antitrust and corporate law, and covenants to govern the

${ }^{79}$ For an example, see section 8.2 .7 of tinyurl.com/p383kc7.

${ }^{80}$ For an example, see section 6.7 of tinyurl.com/nlfu6c3 (calling for a transition services agreement).

${ }^{81}$ Miller 2009a, 2009b, argues that MAC exceptions are intended to reduce opportunistic efforts by buyers suffering from buyers' remorse from invoking MAC clauses as a litigation construct. 
process of complying or to allocate risks associated with those requirements.

Communications between parties to M\&A transactions - including communications leading up to or even included within an M\&A contract - are "regulated" by tort law, and particularly the law of fraud and negligent misrepresentation, ${ }^{82}$ as well as federal securities law when stock is either being purchased or issued in the deal. ${ }^{83}$ Contract provisions attempting to limit or expand such liability by conceding reliance (or non-reliance) on or knowledge (or the lack of knowledge) of potential misstatements are common. Contract law doctrines can make a term sheet or letter of intent that on its face would appear to a nonspecialist to be non-binding into a binding contract, making clearly stated disclaimers of any intend to be bound a practically important component of preliminary agreements. ${ }^{84}$ Fiduciary duties can override, or be found to be violated by, contract provisions that purport to bind fiduciaries in ways that courts applying corporate or agency law find problematic. ${ }^{85}$ Fiduciary duty case law shapes the contents of M\&A contracts in deals for public targets, particularly as regards standstills, process covenants (such as no-shop, no-help and no-talk clauses), termination rights, and break fees.

M\&A contracts are even more strongly shaped by ownership patterns, which are in turn driven by fundamental trade-offs between liquidity and control, as well as regulation of corporate governance and securities markets, as shown in Coates 2010. In general terms, dispersed liquid ownership of target companies leads to the imposition of fiduciary duties and securities law obligations, which in turn constrain M\&A deals to lengthy signing-toclosing periods, the risk of topping bids, and higher transaction costs for complex deal structures. Dispersed target ownership makes post-closing contract enforcement difficult, as former target shareholders continue to be dispersed (and hard to sue effectively), unless consideration is not disbursed, which generates the costs of illiquidity and agency costs. As a result, M\&A contracts for public targets rarely contain meaningful ongoing post-closing covenants, including indemnity clauses (as reflected in Table 2 below), the absence of which in turn makes detailed representations less important, even if they are longer by word count.

Separate process-related effects (as well as specific regulatory risks) arise from antitrust regulation - only deals above a threshold value (currently roughly $\$ 75$ million) require antitrust clearance, and hence delay between signing and closing. Industry-specific

\footnotetext{
82 E.g., Abry Partners V, L.P. v. F \& W Acquisition LLC, 891 A.2d 1032 (Del.Ch. 2006) (dismissing some but not all fraud claims associated with M\&A transaction, based on contract terms and allegedly intentional misrepresentations in the contract). See Coates 2006 for a discussion.

${ }^{83}$ E.g., AES Corp. v. Dow Chemical Co., 325 F.3d 174 (2003) (Rule 10b-5 may be the basis for fraud suit in a stock deal, even one involving sophisticated parties, a single shareholder and a non-listed security).

${ }^{84}$ Schwartz and Scott 2007.

${ }^{85}$ E.g., Ace Ltd. v. Capital Re Corp., 747 A.2d 95 (1999) (interpreting merger contract to avoid conflict between "no-talk" clause and target board's fiduciary duties).
} 
regulation also imposes delay for regulatory approvals on deals in industries such as banking, utilities, and insurance. ${ }^{86}$

Some of the more important effects of ownership dispersion and related regulation are reflected in Table 1 above and Table 2 below. As reflected in Table 1, public target contracts are longer on average than private target contracts, including longer subsections overall, but only rarely include indemnification or special tax articles, and devote less space to defined terms and conditions. As reflected in Table 2, public target deals are less likely to involve "simultaneous" signing/closings, and take longer, on average, to complete, making process management more important, especially fiduciary outs and break fees. Their structures and price provisions are simpler, commonly involving either a one-step triangular merger or a tender offer followed by such a merger, more commonly include either $100 \%$ stock or $100 \%$ cash, rather than a mix or seller financing, as in private target deals. Public target deals rarely include price adjustment clauses or earn-outs. Private target deals, by contrast, commonly involve asset purchases, as well as block stock purchases, more use of complex pricing and post-closing risk sharing. ${ }^{87}$

\section{[Insert Table 2 About Here]}

Delaware is more commonly chosen as the law or forum for disputes in public target deals, as is an agreement to rely on specific performance over damages, consistent with enforcement costs in damage suits being higher for public target deals, while alternative dispute resolution is more common for private target deals, consistent with efforts to minimize litigation costs in disputes over the complex price and risk sharing provisions that are common in private target deals.

\section{Empirical research on the contents and effects of M\&A contracts}

Until recently, few empirical studies have focused on the contents of M\&A contracts. Studies have tended to focus on provisions made salient by litigated disputes, such as MAC clauses, earn-outs, and break fees, as well as on dispute management provisions specifically designed to manage litigation. ${ }^{88}$

\footnotetext{
86 See Coates and Subramanian for a discussion.

87 These differences are not absolute: some public target deals include contingent value rights (equivalent to earn-outs) or mixed consideration, and some private target deals are structured as simple one-step triangular mergers for $100 \%$ cash.

${ }^{88}$ Manns and Anderson 2013 purport to show market prices do not react to the filing of public target deal agreements, which they argue shows that such agreements do not add value on average to baseline non-legal expectations about deals. However, they do not present data on the power of their statistical tests, and while they acknowledge (in note 106) that "there could be significant relationships we fail to uncover because the [Wilcoxon] test [which they use] is less powerful than the t-test," they do not appear to understand the generality of this point, or that without good data and a well-specified model of how stock prices should be expected to react, on average, to the filing of an agreement, the absence of evidence is not evidence of an absence. Their inferences require (as they note) the semi-strong efficient market hypothesis to hold, which in
} 


\section{a. Research on MACs}

Miller 2009 notes that M\&A contracts typically use a single definition for MAC and use the same definition to condition obligations of both buyers and targets, inconsistent with standard models of efficient risk shifting. Miller 2009 also breaks "risk" down into four types - systematic, indicator (e.g., meeting earnings targets), agreement (e.g., loss of customers due to the deal announcement), and a residual "business" category, and finds that MACs in the mid-2000s tended to allocate only the last category of risk to the party making a no-MAC representation, and that MAC exceptions were increasing in the 2000s. Gilson and Schwartz 2005 and Denis and Macias 2013 find that typical MAC clauses changed in the 2000s, growing longer and containing more exceptions. Denis and Macias report fourteen specified types of exclusions, and when they break the exclusions down by industry, the "miscellaneous" category - a residual category of atypical exclusions - generally amounts to less than $10 \%$ of deals in a given industry. Contracts for targets in high technology companies exhibited earlier expansions in MAC exclusions than in other industries, ${ }^{89}$ and remain most likely to specifically exclude stock prices from the MAC definition. ${ }^{90}$ In tension with these trends, Talley develops various measures of the scope of MAC coverage and finds that they generally relate positively to the VIX "fear" index - the implied volatility of the S\&P 500 - but not to target beta, a conventional measure of a firm's systematic (undiversifiable) risk, and interprets the results as suggesting that MACs address Knightian uncertainty or ambiguity rather than conventionally understood risk. MAC exceptions have continued to increase, however, even after the financial crisis (during which period the VIX subsided from its all-time highs), suggesting that uncertainty alone, at least as proxied by the VIX index, cannot explain MAC design and scope.

b. Research on break fees and reverse break fees

Empirical research on break fees was initiated by Coates \& Subramanian 2001, who studied break fees and other forms of deal protection granted by US targets in friendly bids for control greater than $\$ 50$ million in value in the period 1988 to 1999 . They found that fee size correlated with court decisions, including 1994 and 1997 Delaware Supreme Court decisions in Paramount and Brazen, and with other bid characteristics, including larger bid size and the

the case of legal provisions (which require expertise to analyze) is not a consensus assumption. E.g., Bebchuk et al. 2013 (presenting evidence that market prices failed to reflect significance of corporate governance provisions for many years). While well-informed risk arbitrageurs do focus on deals and deal contracts, there are well-known limits to short-selling that constrain arbitrage even in true arbitrage settings, e.g., Shleifer and Vishny 1997, which allow significant pricing "anomalies" to persist, much less in settings (such as the M\&A market) when the "arbitrage" is not true arbitrage but a speculative investment about the likelihood of a deal closing. Finally, they claim that cross-section studies of agreements (which they do not conduct) "are unlikely to discover significant relationships between specific legal provisions and target stock prices," then note one study that did precisely that - Denis and Macias's study of MACs - but then fail to explain why their assertion should be believed given that others have done precisely what they suggest is "unlikely."

${ }^{89}$ Gilson and Schwatz 2005.

${ }^{90}$ Denis and Macias 2013. 
use of a tender offer by the bidder. They also found, in both univariate and multivariate tests, that the fact and size of break fees correlated with completion rates, both in general and conditional on publicly reported bid competition. They found that break fee size was dispersed and grew non-monotonically throughout that period, ranging from $1 \%\left(25^{\text {th }}\right.$ percentile) to $3 \%\left(75^{\text {th }}\right.$ percentile $)$ in 1988 and from $2 \%\left(25^{\text {th }}\right)$ to $4 \%\left(75^{\text {th }}\right)$ in 1999 , consistent with a potential "Lake Woebegone effect," in which bidders sought a fee that was slightly larger than the average fee in a recent period sample, producing ever-increasing fees. ${ }^{91}$ Subsequent research, using US data 1988 to 2000, confirmed these findings. Davidoff and Sautter 2013 discuss changes over time in use of deal protections, including stock option agreements. ${ }^{92}$

Afsharipour 2010 finds that $55 \%$ of a sample of strategic M\&A transactions with reverse break fees in the period 2003 to 2004 were triggered by termination in connection with a competing transaction for the buyer, while $9 \%$ were triggered by failure to obtain regulatory approval and 6\% were triggered by financing failure. Davidoff 2009 at Figure 3 and 497 founds that the "use of financing conditions in [buyout] acquisition agreements dropped [2005 to 2008] in inverse proportion to the utilization of reverse break fees." Table 3 shows that reverse break fees became increasingly linked to financing risk in the mid-2000s, however.

\section{[Insert Table 3 About Here]}

Tucker and Yingling 2009 report that reverse break fees were linked to antitrust risk in about $10 \%$ of deals in the 2000 s, that the incidence of such fees did not increase during or after the financial crisis, that the size of the reverse fees did decline during the 2007-2008 period, and that ticking fees triggered by antitrust delays appeared in M\&A contracts in during 2008.

\section{c. Research on earn-out clauses}

Earn-out incidence appears to vary significantly across time periods and samples of deals. Cain et al. 2011 find earnouts in 4\% of all reported deals in Thomson's M\&A database 19942003; Datar et al. 2001 finding them in 4\% in a sample of deals 1996-1997; Kohers and Ang

\footnotetext{
${ }^{91}$ Boone \& Mulherin 2006 find (and Andre et al. 2007 confirm) that Thomson's data on break fee incidence is biased in several respects: first, there is a general underreporting of fees and other forms of deal protection, relative to what is revealed by a careful review of SEC filings; second, there is a greater underreporting earlier in time, creating the spurious impression of time trends in fee incidence; and third, there is greater underreporting for smaller bids, creating the spurious impression of a relationship between toeholds and break fees. Since these biases emerge from underreporting by Thomson, they should not affect data on fee size, since such data is only available where Thomson reports fee data. They also confirm the finding, reported in Coates \& Subramanian 2001, that fee incidence increased significantly after the 1994 Delaware Supreme Court decision in Paramount.

92 Officer 2003, Bates \& Lemmon 2001. Andre et al. 2007 study break fees in Canada and reach similar conclusions. Chapple et al. 2007 study break fees in Australia, and Coates 2011 compares break fee size and effects in the UK and the US.
} 
2000 find them in 6\% of deals 1984 -1996; and Quinn 2012 finds them in 3\% of deals 20062009; and from 2006 to 2010, earn-out use reported in ABA studies doubled from 19\% to $38 \%$, consistent with the appeal of earn-outs increasing as uncertainty (risk) in the economic and financial environment increases. Coates 2012c finds that in 2007-2008, earn-outs were less common than other risk-sharing clauses (such as indemnities and price-adjustment clauses) in M\&A contracts.

Quinn 2012 found that a third of earn-outs do not produce any payments in the two years following deal announcements, and of those that do produce payouts, the payments were substantially below the maximum possible payout $42 \%$ in the first year, $68 \%$ in the second year). Based on Quinn, Coates 2012 estimates that earn-outs typically have an expected value equal to $\sim 15 \%$ of the overall deal consideration. Consistent with the evidence in Table 2 above, Cain, et al. 2011 find that earn-outs are more common in private target deals than public target deals. They also report that the size (but not the sensitivity) of earn-outs is correlated with measures of risk or uncertainty, including the standard deviation of daily returns over the prior year for the median firm operating in the same industry as the target; the target industry median ratio of R\&D to sales, and the target industry median Tobin's Q. Datar, et al. 2001 and Ragozzino and Reuer 2009 find that earn-outs are more common in cross-industry deals, but Cain et al. 2011 do not. Kohers and Ang 2000 and Datar, et al. 2001 find earn-outs are more common in high-tech and business services sectors than in other industries. Coates 2012c reports that earn-outs are more varied in their details than price adjustments or indemnities, and are equally complex as measured by the numbers of metrics used. ${ }^{93}$

\section{d. Research on dispute management provisions}

Several recent studies have analyzed dispute management provisions. Eisenberg \& Miller 2006 find New York does better than Delaware in attracting designations as choice of forum in M\&A contracts overall, after accounting for the parties' states of incorporation; Price 2008 finds that $57 \%$ of M\&A contracts from 2006 choose Delaware law, 41\% choose Delaware as forum, and 29\% do not choose a forum at all; Cain \& Davidoff 2010 find that Delaware is more frequently designated in choice of law clauses in public target deal agreements, and continued to gain market share in the 2000s; and Coates 2012a finds that while Delaware courts retain a large share $(75 \%)$ of M\&A contract designations as the choice of forum when the targets are public and incorporated in Delaware, Delaware only obtain a modest number of designations in deals involving public companies incorporated outside of Delaware, and Delaware courts are never chosen in bids for private non-Delaware companies, and other courts are chosen about as often (50\% vs. 53\%) in bids for private Delaware targets as for private non-Delaware targets. Coates 2012 also finds that crossborder deals are less likely to fail to designate a forum for disputes, and much more likely to

\footnotetext{
93 See example at note 68 supra.
} 
include an arbitration clauses covering the entire contract. Coates 2012a also finds that specific performance clauses have been typical in M\&A contracts in deals involving strategic buyers using equity to fund the acquisition, but such clauses have been relatively uncommon in debt-financed buyouts, as shown in Practical Law Company 2010. Most recently, Palia and Scott 2014 find in a sample of 500 public target deals from 2001 to 2011, 60\% have jury waiver clauses, jury waivers are more common when New York is chosen as the forum for disputes, that jury waivers are more common in deals involving New York law firms, and when large buyers acquire relatively small targets.

\section{e. Research on other M\&A contract provisions}

Beyond these clauses, and a large body of research in finance on deal currency, ${ }^{94}$ empirical research on M\&A contracts is scarce. One study - Schwartz and Scott 2007 - focuses on disputes involving preliminary agreements, and finds that in a sample of 102 reported cases involving letters of intent, plaintiffs convince a court to find a intent to bind on the underlying agreement in $32 \%$ of the disputes, have cases dismissed in $37 \%$, and persuade the court to find a preliminary agreement or duty to bargain in good faith in $31 \%$ of disputes. In an overlapping sample of 105 reported cases involving claims based on preliminary negotiations or agreements, they find that the courts find contract liability in roughly $35 \%$ of cases, no intent to be bound in just under $30 \%$, and some intermediate form of liability in the remainder.

In studies of core M\&A deal agreements, Officer 2004 finds that of 1,127 deals for public targets using at least some stock as deal currency between 1991 and 1999, roughly 17\% use some type of collar, split roughly one-third fixed exchange ratio collars ("Egyptians") and two-third fixed price collars ("Travoltas"), and that deal pricing has significantly lower elasticity (i.e., more cash, or more use of fixed price collars) when buyers has high marketrelated return standard deviations and targets have low market-related risk. Coates 2012b, 2012c studies risk sharing provisions, including price adjustment clauses and indemnities, along with earn-outs, and finds that they are much more common in private target deals and are designed to address both traditional asymmetric information and moral hazard concerns, correlating with proxies for firm- and industry-risks, as well as including design elements common in insurance contracts, such as deductibles, co-insurance and caps, and also that they are designed to minimize enforcement costs, in part by relying on a variety of focal points and on "support" provisions such as escrows and holdbacks. Subramanian 2008 finds that go-shops and match rights became common in private equity-led buyouts in the mid-2000s, and that go-shops yielded more search and higher returns to target shareholders than traditional no-shops in those deals. Whitehead 2011 analyzes 548 public target contracts from 2007 through 2011 and finds significant variation in the use of anti- or prosandbagging clauses, and also that the use of such clauses does not appear to track in any

\footnotetext{
${ }^{94}$ See generally Betton et al. 2008:320ff (providing partial survey of literature on payment choice).
} 
rational way that underlying default law of tort that would apply to the deals. Wulf 2004 reports basic data on a variety of "social issues" in "mergers of equals," and finds that overall the contracts appear to be crafted to trade-off managerial control for shareholder value.

Conclusion: Research Agenda

This chapter has related M\&A contracts to the purposes of contracts generally, and to specific purposes of contracts in the M\&A setting. After reviewing the broad suite of contracts that occur during the overall M\&A process, the chapter analyzed the contents of a representative sample of US target M\&A deal contracts, using both the authors' own formal organization into articles and a functional analysis relating their contents to goals of M\&A contracts. Along the way, specific examples of important M\&A contract provisions were discussed. Research showing the powerful force of ownership and ownership-related regulation was summarized, and data presented on the many dimensions on which ownership affects the contents of M\&A contracts. The chapter ended with a broader canvas of the increasing number of empirical studies of M\&A contracts.

Going forward, much of the contents of M\&A contracts remain unexplored by academic research, and many practitioners could learn from careful studies relating M\&A provisions to both antecedents and outcomes, such as deal completion, stock price reactions, and litigation. As reflected in the above summary, M\&A contracts continue to exhibit wide variation, even within major classes of deal types - an ideal setting for empirical work to bring statistical methods to bear to explore how contracts respond to various forces. Among the many unexplored parts of M\&A contracts are negative covenants, which vary significantly by industry and firm; conditions (other than MACs), particularly those anchored in representations, which provide an underappreciated set of "outs" for buyers who may seek to get out of a deal; and processing covenants, which can shift important dealcompletion risks from one party to another. Also largely unexplored are the patterns among M\&A contract terms, which are typically chosen together in a package of negotiated terms. Indexes of buyer- or target-friendliness of deal terms could be developed, to see if deal terms favorable to one party are offset by terms favorable to another, or whether they have observable effects on price, or on market reception of the deals. Finally, patterns of M\&A contract evolution over time remain almost completely unexplored - the tentative finding presented here, that otherwise similar M\&A deals now generate significantly longer contracts than 20 years ago is just the tip of an iceberg of what could be learned about how legal innovation occurs and diffuses and, correspondingly, whether and to what extent lawyers add value to the M\&A process.

\section{References}

Afra Afsharipour, Transforming the Allocation of Deal Risk Through Reverse Termination Fees, 63 Vand. L. Rev. 1161 (2010) 
American Bar Association, Merger \& Acquisitions Comm., Model Merger Agreement for the Acquisition of a Public Company (2011)

American Bar Association M\&A Market Trends Subcommittee of the Committee on Negotiated Acquisitions, Private Equity Buyer / Public Target Mergers \& Acquisitions Deal Points Study (Sep. 2007)

P. Andre, S. Khalil, and M. Magnan, Termination Fees in Mergers and Acquisitions:

Protecting Investors or Managers?, 34 J. Bus. Fin. \& Acct'g 541 (2007)

Ulf Axelson, Tim Jenkinson, Per Stromberg and Michael S. Weisbach, Borrow Cheap, Buy High?, The Determinants of Leverage and Pricing in Buyouts, 68 J. Fin. 2223 (2013)

Karl F. Balz, No-Shop Clauses, 28 DeL. J. CoRP. L. 513 (2003)

T.W. Bates and M. L. Lemmon, Breaking Up Is Hard to Do? An Analysis of Termination Fee Provisions and Merger Outcomes, 69 J. Fin. Econ. 469 (2003)

Lucian Bebchuk, Alma Cohen and Charles C.Y. Wang, Learning and the Disappearing Association Between Governance and Returns, 108 J. Fin. Econ. 323 (2013)

Sandra Betton, B. Espen Eckbo, and Karin S. Thorburn, Corporate Takeovers, in Handbook of Empirical Corporate Finance, Volume 2 (2008)

A.L. Boone and J. H. Mulherin, Do Termination Provisions Truncate the Takeover Bidding Process?, 20 Rev. Fin. Stud. 461 (2007)

Robert F. Bruner, Applied Mergers and Acquisitions (2004)

T.R. Burch, Locking Out Rival Acquirers: The Use of Lockup Options in Corporate Mergers, 60 J. Fin. Econ. 103 (2001)

M.D. Cain, D. J. Denis, and D. K. Denis, Earnouts: A Study of Financial Contracting in Acquisition Agreements, 51 J. Acct'g Econ. 151 (2011)

Matthew D. Cain \& Steven M. Davidoff, Delaware's Competitive Reach, 9 J. Empirical Legal Stud. 92 (2012)

Adam D. Chinn, Nancy M. Clark, John C. Coates IV, Edward D. Herlihy, David S. Neill, and Craig M. Wasserman, Mergers and Acquisitions of Financial Institutions - 1995: An Unprecedented Year of Consolidation, Securities Activities of Banks, Fifteenth Annual Institute (1995)

John C. Coates, Contracting to Lie: A Discussion of Abry Partners v. F\&W Acquisition (Del. Ch. 2006), Legalworks 22nd Annual Mergers \& Acquisitions Institute (May 17, 2006) 
John C. Coates, The Powerful and Pervasive Effects of Ownership on M\&A, Olin Center Discussion Paper No. 669 (June 2010), available at ssrn.com/abstract $=1544500$

John C. Coates, 2012a, Managing Disputes Through Contract: Evidence from M\&A, 2 Harv. Bus. L. Rev. 301-349 (2012)

John C. Coates, 2012b, Evidence-Based M\&A: Less Can Be More When Allocating Risk in Deal Contracts, J. Int'l Banking \& Fin. L. 708 (Dec. 2012)

John C. Coates, 2012c, Allocating Risk Through Contract: Evidence from M\&A and Policy Implications, Working Paper (Aug. 2012), available at ssrn.com/abstract $=2133343$

John C. Coates IV, M\&A Break Fees: U.S. Litigation vs. U.K. Regulation, in Regulation versus Litigation: Perspectives from Economics and Law 255, 262-63 (Daniel Kessler ed., Chicago University Press, 2011)

John C. Coates IV, Mergers, Acquisitions, and Restructuring: Types, Regulation, and Patterns of Practice (July 2014), available at ssrn.com/abstract=2463251 (last visited Mar. 20, 2015), forthcoming in Oxford Handbook On Corporate Law And Governance (eds. J. Gordon and G. Ringe, Oxford University Press 2015)

John C. Coates IV \& Guhan Subramanian, A Buy-Side Model of M\&A Lockups: Theory and Evidence, 53 Stan. L. Rev. 307 (2000)

Srikant Datar, Richard Frankel and Mark Wolfson, Earnouts: The Effects of Diverse Selection and Agency Costs on Acquisition Techniques, 17 J.L.Econ. \& Org. 201 (2001)

Steven M. Davidoff and Christina M. Sautter, Lock-Up Creep, 38 J. Corp. L. 681 (2013)

Steven M. Davidoff, The Failure of Private Equity, 82 S. Cal. L. Rev. 481 (2009)

D. DeChiara, R. Porter, and M. Abascal, MAC Survey: A Nixon Peabody Study of Current Negotiation Trends of Material Adverse Change Clauses in M\&A Transactions (2007), available at www.nixonpeabody.com/publications detail3.asp?ID=2474 (last visited March 20, 2015)

David J. Denis and Antonio J. Macias, Material Adverse Change Clauses and Acquisition Dynamics, 48 J. Fin. Quant. Anal. 819 (2013)

Theodore Eisenberg \& Geoffrey Miller, Ex Ante Choices of Law and Forum: An Empirical Analysis of Corporate Merger Agreements, 59 Vand. L. Rev. 1975 (2006)

Theodore Eisenberg \& Geoffrey P. Miller, The Flight from Arbitration: An Empirical Study of Ex Ante Arbitration Clauses in the Contracts of Publicly Held Companies, 56 DEPAUL L. REV. 335 (2007) 
Lily H. Fang, Victoria Ivashina, and Josh Lerner, Combining Banking with Private Equity Investing, 26 Review of Financial Studies 2139 (September 2013)

Charles M. Fox, Working with Contracts: What Law School Doesn't Teach You, 14 (2nd ed. 2008)

Jorge L. Freeland and Nicholas D. Burnett, 2008 Survey Of Private Company Purchase Price Adjustments, M\&A Lawyer (June 2009)

James C. Freund, Anatomy of a Merger (1975, rev ed. 2008)

Ronald J. Gilson, Value Creation by Business Lawyers: Legal Skills and Asset Pricing, 94 Yale L.J. 239 (1984)

R. J. Gilson and A. Schwartz, Understanding MACs: Moral Hazard in Acquisitions, 21 Journal of Law, Economics, and Organization 330 (2005)

Victor P. Goldberg, Framing Contract Law: An Economic Perspective (2006)

Claire A. Hill, Language and Norms in Complex Business Contracting, 77 Chi.-Kent L. Rev. $1(2001)$

Claire A. Hill, Bargaining in the Shadow of a Lawsuit: A Social Norms Theory of Incomplete Contracts, 34 Del. J. Corp. L. 1 (2009)

Claire A. Hill, Why Are Non-US Contracts Written in US Legalese? Some Preliminary Thoughts and a Research Agenda, in Law and Language (Michael Freeman \& Fiona Smith, eds., Oxford University Press, 2013)

Victoria Ivashina and Zheng Sun, Institutional Demand Pressure and the Cost of Corporate Loans, 99 J. Fin. Econ. 500 (March 2011)

Louis Kaplow and Steve Shavell, Contracting (2004)

Marcel Kahan \& Michael Klausner, Standardization and Innovation in Corporate

Contracting (or "The Economics of Boilerplate"), 83 Va. L. Rev. 713 (1997)

Lou R. Kling \& Eileen T. Nugent, Negotiated Acquisitions of Companies, Subsidiaries and Divisions (2000)

Ninon Kohers and James Ang, Earnouts in Mergers: Agreeing to Disagree and Agreeing to Stay, 73 J. Bus. 445 (2000)

Jason Scott Johnston, The Statute of Frauds and Business Norms: A Testable GameTheoretic Model, 144 U. Pa. L. Rev. 1859 (1996)

Igor Kirman, M\&A and Private Equity Confidentiality Agreements Line by Line (2008) 
Russell Korobkin, The Status Quo Bias and Contract Default Rules, 83 Cornell L. Rev. 608 (1998)

Jeffrey Manns and Robert Anderson IV, The Merger Agreement Myth, 98 Cornell L. Rev. 1143 (2013)

Robert T. Miller, Canceling the Deal: Two Models of Material Adverse Change Clauses in Business Combination Agreements, 31 Cardozo L. Rev. 99 (2009a)

Robert T. Miller, The Economics of Deal Risk: Allocating Risk Through MAC Clauses in Business Combination Agreements, 50 Wm. \& Mary L. Rev. 2007 (2009b)

Eileen T. Nugent, Record Year Brings More Risk in Deal Terms: As Market Competition and the Size of Consortia Have Increased, Provisions of Acquisition Agreements Have Changed, International Financial Law Review, Guide to Mergers and Acquisitions (2006)

Micah S. Officer, Termination Fees in Mergers and Acquisitions, 69 J. Fin. Econ. 431 (2003)

Micah S. Officer, Collars and Renegotiation in Mergers and Acquisitions, 59 J. Fin. 2719 (2004)

Darius Palia and Robert E. Scott, Ex Ante Choice of Jury Waiver Clauses in Mergers, Working Paper (2014)

Brian E. Price, Strategic Choices in Merger Agreements: A Study of Decisions to Choose (And Not to Choose) Law and Forum, 4 N.Y.U. J. L. \& Bus. 647, 657-58 (2008)

Brian J.M. Quinn, Optionality in Merger Agreements, 35 Del. J. Corp. L. 789 (2010)

Brian JM Quinn, Re-Evaluating the Emerging Standard of Review for Matching Rights in Control Transactions, 36 Del. J. Corp. L. 1011 (2011)

Brian J.M. Quinn, Putting Your Money Where Your Mouth Is: The Performance of Earnouts in Corporate Acquisitions, 81 U. Cin. L. Rev. 127 (2012)

Roberto Ragozzino and Jeffrey J. Reuer, Contingent Earnouts in Acquisitions of Privately Held Targets, 35 J. Mgt. 1 (2009)

Todd Rakoff, Contracts of Adhesion: An Essay in Reconstruction, 96 Harv. L. Rev. 1173 (1983)

Robert Reilly, Procedural Checklist for the Review of Solvency Opinions, 27-6 American Bankruptcy Institute Journal 50 (2008)

Eric M. Rosof et al., Acquisition Financing: The Year Behind and the Year Ahead, Client Memo (Jan. 31, 2013) 
Id., Acquisition Financing: The Year Behind and the Year Ahead, Client Memo (Feb. 18, 2014)

Christina M. Sautter, 2013a, Promises Made to Be Broken? Standstill Agreements in Change of Control Transactions, 37 Del. J. Corp. L. 929 (2013)

Christina M. Sautter, 2013b, Auction Theory and Standstills: Dealing with Friends and Foes in a Sale of Corporate Control, Case W. Res. L. Rev. (2013)

Christina M. Sautter, Shopping During Extended Store Hours: From No Shops to GoShops, 73 Brooklyn L. Rev. 525 (2008)

Andrei Shleifer and Robert Vishny, The Limits of Arbitrage, 52 J. Fin. 35 (1997)

Slaughter and May, Financing Briefing (July 2008)

Alan Schwartz and Robert Scott, Precontractual Liability And Preliminary Agreements, 120 Harv. L. Rev. 661 (2007)

David J. Sorkin and Eric M. Swedenburg, Recent Developments in Financing-Related Provisions in Leveraged Buyouts, Simpson Thacher Client Memo (January 2006)

Guhan Subramanian, Matching Rights: A Boon to Both Sides, Harvard Bus. Rev. (Dec. 1, 2005)

Guhan Subramanian, Go-Shops vs. No-Shops in Private Equity Deals: Evidence and Implications, 63 Bus. Law. 729 (2008)

Thomas A. Swett, Merger Terminations After Bell Atlantic: Applying a Liquidated Damages Analysis to Termination Fee Provisions, 70 U. Colo. L. Rev. 341 (1999)

Eric L. Talley, On Uncertainty, Ambiguity, and Contractual Conditions, 34 Del. J. Corp. L. 755 (2009)

Mark B. Tresnowski, The Anatomy of Working Capital Purchase Price Adjustment Provisions In Acquisition Agreements, Practising Law Institute, 1742 PLI/Corp 561 (2009)

Darren S. Tucker and Kevin L. Yingling, Keeping the Engagement Ring: Apportioning Antitrust Risk with Reverse Breakup Fees, 22 SUM-Antitrust 70 (2008)

Russell J. Weintraub, A Survey of Contract Practice and Policy, 1992 Wis. L. Rev. 1 (1992)

Peter J. Whitmore, A Statistical Analysis of Noncompetition Clauses in Employment Contracts, 15 J. Corp. L. 483 (1990)

Charles K. Whitehead, Sandbagging: Default Rules and Acquisition Agreements, 36 Del. J. Corp. L. 1081 (2011) 
Julie Wulf, Do CEOs in Mergers Trade Power for Premium? Evidence from "Mergers of Equals", 20 J.L. Econ \& Org. 60 (2004)

Practical Law Company, Reverse Break-Up Fees and Specific Performance: A Survey of Remedies in Public Deals (Practical Law Company 2010) 
Table 1 Formal organization and length (in words) of M\&A contracts

\begin{tabular}{|c|c|c|c|c|c|}
\hline Article & $\begin{array}{c}\text { Mean } \\
\text { (median) }[\%] \\
\text { words, all } \\
\text { contracts }\end{array}$ & $\begin{array}{c}\text { Public target } \\
\text { deal } \\
\text { contracts }\end{array}$ & $\begin{array}{c}\text { Private target } \\
\text { deal } \\
\text { contracts }\end{array}$ & $\begin{array}{c}\text { IBM / Lotus } \\
\text { Agreement, } \\
1994\end{array}$ & $\begin{array}{c}\text { Publicis / } \\
\text { Sapient } \\
\text { Agreement, } \\
2014\end{array}$ \\
\hline \multirow[t]{2}{*}{ Recitals } & $283(225)$ & 354 & 211 & 419 & 423 \\
\hline & {$[1 \%]$} & {$[1 \%]$} & {$[<1 \%]$} & {$[2 \%]$} & {$[1 \%]$} \\
\hline \multirow{2}{*}{$\begin{array}{r}\text { Price, currency and } \\
\text { structure }\end{array}$} & $3,261(3,165)$ & 4,021 & 2,501 & 2966 & 4779 \\
\hline & {$[11 \%]$} & {$[12 \%]$} & {$[8 \%]$} & {$[14 \%]$} & {$[12 \%]$} \\
\hline \multirow[t]{2}{*}{ Representations } & $11,139(11,239)$ & 11,504 & 10,061 & 6480 & 14191 \\
\hline & {$[39 \%]$} & {$[37 \%]$} & {$[33 \%]$} & {$[30 \%]$} & {$[36 \%]$} \\
\hline \multirow[t]{2}{*}{ Target reps } & $8,361(8,663)$ & 8,916 & 8,916 & 5490 & 12790 \\
\hline & {$[30 \%]$} & {$[28 \%]$} & {$[26 \%]$} & {$[25 \%]$} & {$[32 \%]$} \\
\hline \multirow[t]{2}{*}{ Buyer reps } & $2,216(1,316)$ & 2,544 & 7,797 & 990 & 1401 \\
\hline & {$[9 \%]$} & {$[8 \%]$} & {$[6 \%]$} & {$[5 \%]$} & {$[4 \%]$} \\
\hline \multirow[t]{2}{*}{ Covenants } & $5,875(6,214)$ & 2,544 & 1,883 & 5434 & 12950 \\
\hline & {$[20 \%]$} & {$[23 \%]$} & {$[15 \%]$} & {$[25 \%]$} & {$[33 \%]$} \\
\hline \multirow[t]{2}{*}{ Conditions } & $1,297(1,249)$ & 1,201 & 1,393 & 1239 & 1316 \\
\hline & {$[5 \%]$} & {$[4 \%]$} & {$[5 \%]$} & {$[6 \%]$} & {$[3 \%]$} \\
\hline \multirow[t]{2}{*}{ Termination } & 997 (713) & 1,444 & 551 & 921 & 1380 \\
\hline & {$[3 \%]$} & {$[5 \%]$} & {$[2 \%]$} & {$[4 \%]$} & {$[4 \%]$} \\
\hline \multirow[t]{2}{*}{ Indemnification } & $1,177(308)$ & 134 & 2,220 & 0 & 0 \\
\hline & {$[4 \%]$} & {$[<1 \%]$} & {$[7 \%]$} & {$[0 \%]$} & {$[0 \%]$} \\
\hline \multirow[t]{2}{*}{ Tax } & $457(0)$ & 0 & 914 & 0 & 0 \\
\hline & {$[2 \%]$} & {$[<1 \%]$} & {$[3 \%]$} & {$[0 \%]$} & {$[0 \%]$} \\
\hline \multirow[t]{2}{*}{ Defined terms } & $2,573(2,392)$ & 1,962 & 3,185 & 0 & 0 \\
\hline & {$[9 \%]$} & {$[6 \%]$} & {$[10 \%]$} & {$[0 \%]$} & {$[0 \%]$} \\
\hline \multirow[t]{2}{*}{ Miscellaneous } & $1,695(1,689)$ & 1,444 & 1,945 & 856 & 3282 \\
\hline & {$[6 \%]$} & {$[5 \%]$} & {$[6 \%]$} & {$[4 \%]$} & {$[8 \%]$} \\
\hline Total & $31,093(31,435)$ & 31,518 & 30,531 & 21,675 & 39,424 \\
\hline
\end{tabular}


Table 2. Characteristics of M\&A Contracts, by Ownership and SEC Regulation of the Target

\begin{tabular}{|c|c|c|c|}
\hline Deal timing & \multicolumn{2}{|c|}{$(\mathrm{n}=60$ unless noted $)$} & $\begin{array}{c}\text { P-value of t-test, } \\
\text { Wilcoxon test, or } \\
\text { F-test }\end{array}$ \\
\hline Simultaneous sign/close & $3 \%$ & $22 \%$ & 0.00 \\
\hline Simultaneous if $<\$ 63 \mathrm{MM}$ & $7 \%(n=28)$ & $36 \%(n=33)$ & 0.00 \\
\hline Median non-zero duration & 83 days $(n=51)$ & 42 days $(n=60)$ & 0.01 \\
\hline Median non-zero duration if $>\$ 63 \mathrm{MM}$ & 94 days $(n=26)$ & 45 days $(n=27)$ & 0.00 \\
\hline \multicolumn{4}{|l|}{ Specification of structure } \\
\hline Merger (one-step) & $67 \%$ & $33 \%$ & 0.00 \\
\hline Tender offer & $22 \%$ & $0 \%$ & 0.00 \\
\hline Block stock purchase & $8 \%$ & $40 \%$ & 0.00 \\
\hline Asset purchase & $0 \%$ & $27 \%$ & 0.00 \\
\hline Multi-step & $25 \%$ & $0 \%$ & 0.00 \\
\hline \multicolumn{4}{|l|}{ Price specification and risk sharing } \\
\hline Mixed consideration & $15 \%$ & $45 \%$ & 0.01 \\
\hline Seller financing (i.e., debt consideration) & $2 \%$ & $22 \%$ & 0.00 \\
\hline Price adjustment clause in contract & $7 \%$ & $67 \%$ & 0.00 \\
\hline Earn-out provision & $2 \%$ & $17 \%$ & 0.00 \\
\hline Target indemnification of buyer post-closing & $7 \%$ & $87 \%$ & 0.00 \\
\hline \multicolumn{4}{|l|}{ Process management } \\
\hline Fiduciary out & $85 \%$ & $10 \%$ & 0.00 \\
\hline Termination fee or stock option lockup & $78 \%$ & $13 \%$ & 0.00 \\
\hline \multicolumn{4}{|l|}{ Dispute management } \\
\hline Delaware as choice of law & $55 \%$ & $22 \%$ & 0.00 \\
\hline Delaware courts as forum & $47 \%$ & $8 \%$ & 0.00 \\
\hline ADR for entire contract & $2 \%$ & $20 \%$ & 0.00 \\
\hline $\begin{array}{l}\text { ADR for price (if price adjustment clause } \\
\text { used) }\end{array}$ & $25 \%(n=4)$ & $89 \%(n=35)$ & 0.00 \\
\hline Agreement to specific performance & $73 \%$ & $48 \%$ & 0.00 \\
\hline
\end{tabular}


Table 3. Examples of Reverse Break Fee Triggers in Transactions 2006-2007

\begin{tabular}{|c|c|c|c|c|}
\hline Target or Seller Name & $\begin{array}{c}\text { Deal } \\
\text { Agreement } \\
\text { Date }\end{array}$ & $\begin{array}{l}\text { Reverse } \\
\text { Superior } \\
\text { Bid Risk } \\
\end{array}$ & $\begin{array}{c}\text { Regulatory } \\
\text { Risk }\end{array}$ & $\begin{array}{c}\text { Financing } \\
\text { Risk }\end{array}$ \\
\hline Acxiom Corp & $5 / 16 / 07$ & & & Yes \\
\hline Alderwoods Group, Inc. & $4 / 2 / 06$ & & Yes & \\
\hline Alliance Data Systems Corp & $5 / 17 / 07$ & & & Yes \\
\hline CDW Corporation & $5 / 29 / 07$ & & & Yes \\
\hline CKX, Inc. & $5 / 31 / 07$ & & & Yes \\
\hline Fisher Scientific International, Inc. & $5 / 7 / 06$ & Yes & & \\
\hline Penn National Gaming & $6 / 15 / 07$ & & Yes & Yes \\
\hline The Yankee Candle Company & $10 / 24 / 06$ & & & Yes \\
\hline Univision Communications Inc & $6 / 26 / 06$ & & Yes & Yes \\
\hline
\end{tabular}

